\title{
LAND PRICE MAPPING OF JABODETABEK, INDONESIA
}

\author{
A. M. Elmanisa ${ }^{\text {a }}$, A. A. Kartiva ${ }^{\text {a }}$, A. Fernando ${ }^{a}$, R. Arianto ${ }^{\text {a }}$, H. Winarso ${ }^{a}$, D. Zulkaidi ${ }^{\text {a }}$ \\ ${ }^{a}$ Research Group in Planning and Policy Development, Bandung Institute of Technology, Indonesia
}

\begin{abstract}
Article Info:
Received: 4 October 2016

in revised form: 17 November 2016

Accepted: 23 February 2017

Available Online: 27 March 2017

Keywords:

Land price, isoline-map, Jakarta, Jabodetabek, GIS

\section{Corresponding Author:}

Adisti Madella Elmanisa Research Group in Planning and Policy Development, Bandung Institute of Technology Indonesia

Abstract: Land provision is one of the biggest challenges for development in urban area. Most of the available urban land will be the object of speculation to be resold at a higher price when the time is right. In Jabodetabek, where the pace of urban development is faster than other parts of Indonesia, the prices of land show an abnormal increase; they seem to rise too fast. This paper discusses the increasing land prices in Jabodetabek area and argues that the increasing land price has encourages the private developer to bank the land in the area. Based on land price survey in Jabodetabek, urban activity is moving to south Jakarta. The highest land prices were found at East Kuningan, Setiabudi, and South Jakarta. By constrast, the lowest prices were observed in Sumur Batu and Cimuning (Bantar Gebang, Bekasi).It can be concluded that the land price increase also triggered land banking practice in Jabodetabek reaching in total approximately $60 \%$ of total area of Jakarta.
\end{abstract} Email: adis.madel@gmail.com

Copyright (C) 2017 GJGP-UNDIP This open access article is distributed under $a$ Creative Commons Attribution (CC-BY-NC-SA) 4.0 International license.

How to cite (APA 6th Style):

Elmanisa, A. M., et al. (2017). Land price mapping of Jabodetabek, Indonesia. Geoplanning: Journal of Geomatics and Planning, 4(1), 53-62. doi:10.14710/geoplanning.4.1.53-62

\section{INTRODUCTION}

Until 2015, within 35 years, the private sectors in Jabodetabek (Jakarta, Bogor, Depok, Tangerang, and Bekasi) have transformed large amount of land in Jakarta and its surrounding areas. By 1997, a countryside land of 16,600 hectares of located outside the built up area, were converted into residential use, and sold about 25,000 units per year (Winarso, 1999; Winarso \& Firman, 2002). This development went further into rural areas and created urban sprawl. Ten years since the 1990s, twenty new cities have emerged.

During the year of 1990 to 1994, changes in land use significantly increased. Land conversions were apparent. In this situation, land ownership concentration clearly was possessed by only few big developers. In1996, more than 1,000 hectares land in Botabek (Bogor, Tangerang, Bekasi) were owned by only 15 companies (Winarso \& Firman, 2002). Furthermore, Winarso (1999) mentioned that land developers companies were working together to determine the land price. In the end, land speculations correspondingly occurred.

Land speculation is an attempt to gain the value of the land that arises from land use change (Hermawan \& Syahbana, 2015). Supply of land is inelastic; therefore, land prices will rise as demand increases. Frequently, the rise of land price does not followed by increase of land availability (land supply). Some owners even put off selling the land, expecting higher price in the future that will result in land supply reduction (Darin-Drabkin, 2013).

The financial industry plays an important role in Jabodetabek land development since this industry provides funding for developers. Its role becomes more important along with enactment series of deregulation policies began in the 1980s. All domestic banks were given the liberty to open new branches and to allow establishment of new private banks. Furthermore, SOEs were allowed to deposit their funds in these banks up to $50 \%$.

Until now, this phenomenon consistently takes place in Jakarta and its surrounding areas. Developers allegedly set the price of land as happened in the 1990s. This might be due to land ownership concentration 
that is yet being acquired by only few large developers. They own nearly all available strategic lands to be built into medium scale housing and finally sell it with high price.

Developers still determine the selling price of the property. For example, Kompas (October, 2014) quoted that "Despite the increasing price of fuel oil has not been officially announced, some developers already prepare to raise the price of housing in January 2015" (Alexander, 2014). The increasing price has direct impact to land supply for low-price housing development, as reported by CNN Finance in November, 2014 in quotation "This condition, land price that continuously increases has caused difficulty for a lowprice housing developers to develop their business" (Supriyadi, 2014).

Urban land study cannot be separated from its role as a major input in city development, where there is transformation from land into built environment. Urban development is a complex process that requires orchestration of financial, material, labor and expertise by various actors in an environment harboring social, economic, political and wider elements. In order to explain the complexity, at least three theoretical approaches could be used as an analysis tools such as neoclassical, neo-marxist and institutional approaches (Healey, 1992; Winarso, 1999).

According to neoclassical approach, urban land use is determined by decisions made by firms and households based on their preferences. Therefore, demand for land will be associated with location, distance proximity to a variety of urban services, availability of facilities, quality of surrounding environment, social factors, transportation, and various other attributes. Finally, neoclassical approach leads to hedonic land price concept. Meanwhile, based on Healey \& Barrett (1990), institutional approach saw land price as an implication of interaction between the financial system, types and strategies of the actors, and the role of policies and interventions influencing the development process and strategies adopted by the actors in it. Moreover, Beckert (2011) saw the price as the implications of the macro-social structure, a network of actors in a market, where the network can determine the price through their effects on its internal competition and create a variety of phenomena such as cartels, monopolies, and other forms of collusion to manipulate the situation market.

Land price determined only by developers may indicate an oligopolistic market/monopoly and unhealthy competition which is feared will cause bubbling, disturbing the property market and infrastructure development (Please See Hu et al., 2016; Liu, Miao, \& Zha, 2016; Liu, Wang, \& Zha, 2013; Tsutsumi \& Seya, 2008; Zhang et al., 2017). It could also lead to a crash. During the second half of $1980^{\text {s, }}$ land price in Japan was on the highest level in two decades and created bubble then crash. Until now, housing price remains a major problem in Japan due to extremely high land price. Based on these descriptions, identification and analysis land price in Indonesia, especially in Jabodetabek becomes indispensable. For that purpose, the gathering of land price information was carried out in Jabodetabek using sampling method. Land price data was then processed and displayed on isoline map using GIS. Moreover, interview processes were conducted and secondary information were collected in order to support the alleged practice of land banking by the developer.

\section{DATA AND METHODS}

\subsection{Sampling}

Selected informants to be interviewed were purposively conducted, as important actors involved in land development process for housing in Jakarta and its surrounding areas. In addition, the snowball method was used to gain access through a network, owned by key informants that have been previously interviewed. The type of sampling used was multistage random sampling: geographical and probability samplings. Geographical sampling was applied to divide the number of units of the study area $(36 \times 18)$. While probabilistic sampling approach was applied for land price mapping with the unit of analysis, as performed by the Dowall \& Leaf (1991) in Jakarta. To give an exact picture without having to conduct a survey in all villages, we used 300 samples out of 539 villages located in the study area (Figure 1).

Each unit which data was taken have the following criteria location (formulated based on research Dowall \& Leaf, 1991): (a) close to the highway, (b) local roads (a residential street), and (c) footpath / alleyway. The process of collecting land price data used sample data that represents the area of Jakarta, Bekasi, Depok City, Kota Tangerang and South Tangerang area where the land is used as residential 
development, with administrative village as the smallest unit. Informants were village officers from government and private agencies / brokers. Composition of collected land price data consisted of two data from a broker and one data from village officers. A total of 9 data at every unit was acquired.

Figure 1. Map of field study

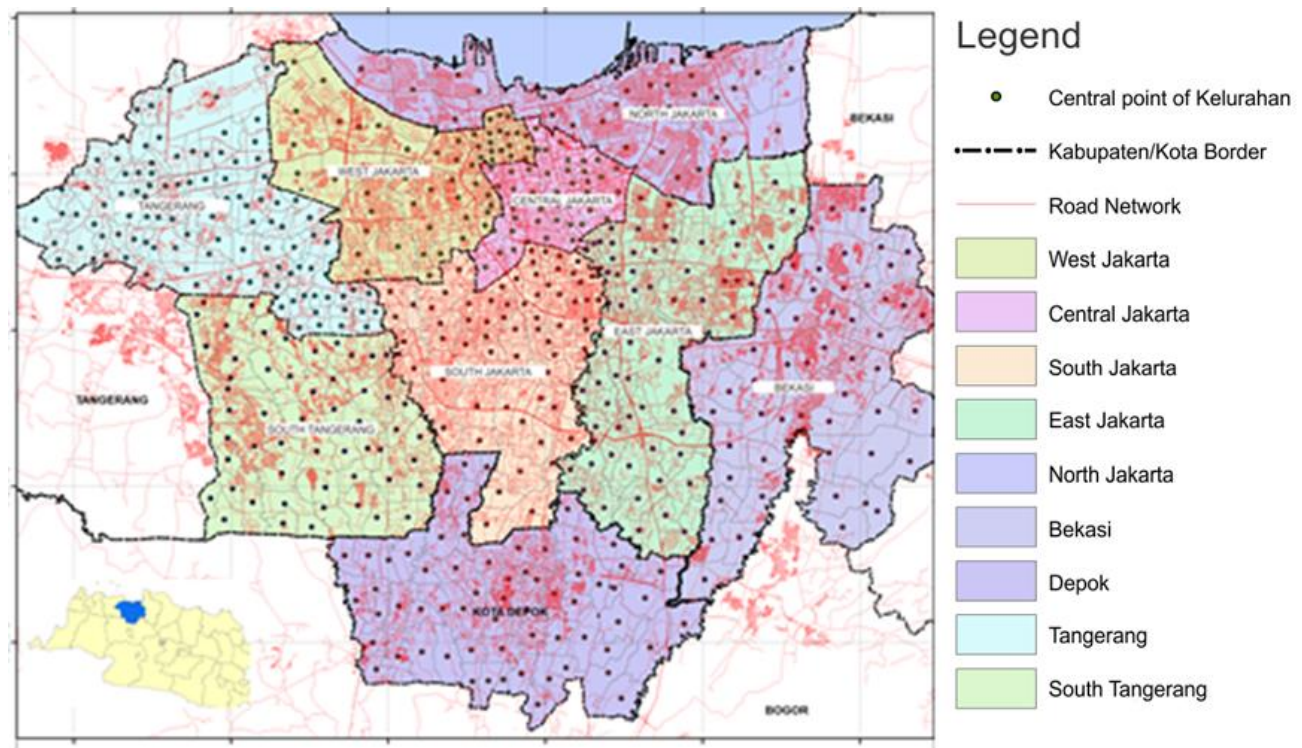

Some used definitions in this paper are: (1) Land price which is the land transaction price (in rupiah); (2) Large Developers which is a company engaged in the development of formal land with an area of at least 50 hectares project (Winarso, 1999); (3) Land Banking meaning land owned by the developer either undeveloped or already developed but not yet vended (in hectares); (4) Administrative village is an administrative staff who understands about land price; and (5) Broker/Realtor is intermediaries in of selling /buying/renting the property with experience of at least 5 years.

\subsection{Data Source}

Land price data sources were acquired from stakeholders or actors involved and played a role in land trading and land price. Stakeholders include the broker/realtor, the large developers and the government. Moreover, data from website, finance magazines and companies history were equally collected.

\subsection{Analysis Method}

Based on Dowall \& Leaf (1991), land price will were analyzed based on information obtained from three informants, if differences were observed, the middle price was taken (median). Based on the availability of infrastructure in each village, land price data were collected from three different locations. Brokers were also asked about land price changes over the last 10 years (since 2005). Land prices were furthermore analyzed based on the characteristics of the plot to observe the difference between some characteristics before shown on map. The map was created with Geographical Information System (GIS) as database and Surfer software as analysis tool. Information related to land banking were obtained from the interviews. To obtain a deeper and wider grounding, secondary data from various sources were also collected such as books, journals, documents of regulations and policies, the Central Statistics Agency (BPS), Bank Indonesia (BI), property analysis reports, articles and reports from media of properties and various other sources.

\section{RESULTS AND DISCUSSION}

\subsection{Land Price in Jabodetabek}

The increase of land prices in urban areas has constantly arisen in countries with strong economic growth and strong urbanization, including in Indonesia (Dowall \& Leaf, 1991; Ferguson \& Hoffman, 1993). The following Figure 2 compared the increasing of land property price between Jabodetabek and 14 other major cities in Indonesia. The data collection was routinely conducted by Bank Indonesia. Property price index describing the development of property prices in 14 major cities had a tendency to increase, but with 
a relatively gentle slope. In contrast, the index of property prices in Jabodetabek experienced a significant acceleration with a steep slope since mid-2011.

Figure 2. The increase in property prices in Greater Jakarta compared with Bank Indonesia Index (Bloomberg, BI, Bank for International Settlements, in East spring Investments Indonesia, 2015)

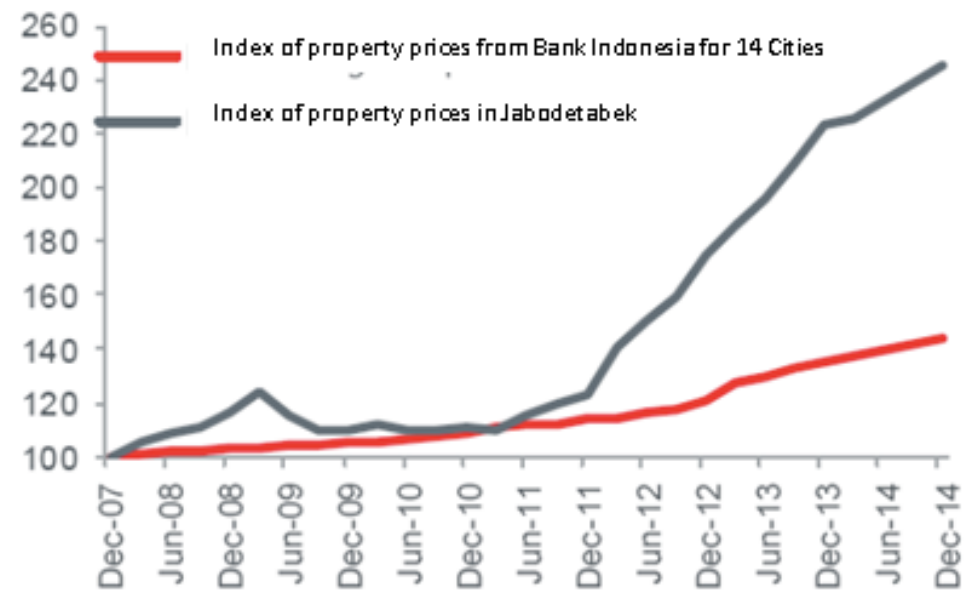

Ferguson \& Hoffman (1993) analyzed land price increases in Jakarta from 1985 to 1990 by comparing it to variety of economic indicators, including consumer price index, various forms of investment, as well as the comparison of price increases occurred in other countries. While Ward, Jimenez, and Jones (1993) conducted a study of land price increases in Mexico in the context of affordability for the poor residents by comparing the increase in land prices with some factors such as: (a) the minimum wage; (b) actual wages based on surveys; (c) the price of basic commodities; and (d) the increase in the price of building materials.

One of data source related to land price increases can be observed via land value data at several major locations in Jakarta as reported by Property Indonesia (November, 2015). Based on the displayed data, the land price increases was projected from two types of prices, which are market prices and tax object sales value (NJOP). Value between NJOP and market price was often unbalanced, where NJOP was much lower than the transaction price. In practice, the actual transaction price was replaced in accordance with NJOP so that the paid tax became much lower than it should have been. Such practices leading to the potential loss of local taxes, hence, anticipation were conducted by increasing NJOP as much as 20-140 percent in 2014, via Jakarta Governor Regulation No. 175/2013.

Recapitulation of land price growth in Jakarta and its surrounding areas from 2011 to 2014 was shown in Table 1. This data were based on the survey conducted in 284 urban villages of Jakarta and its surrounding areas. It included Jakarta (132 villages), Kota Tangerang (45 villages), South Tangerang City (41 villages), Kota Depok (39 villages), and Bekasi City (27 villages) with administrative village officer and also brokers as informants. Both informants were well-informed about the land price growth at each location.

Table 1. The Land Prices Increase in Jakarta and its surrounding areas (Bank Indonesia, 2015)

\begin{tabular}{|c|c|c|c|c|c|}
\hline \multirow{2}{*}{ Area } & \multicolumn{4}{|c|}{ Percentage of Increasing Land Price } & \multirow{2}{*}{ Average } \\
\hline & (2010-2011) & (2011-2012) & (2012-2013) & (2013-2014) & \\
\hline Jakarta & $18.21 \%$ & $21.01 \%$ & $14.65 \%$ & $10.85 \%$ & $16.18 \%$ \\
\hline Tangerang & $28.57 \%$ & $22.22 \%$ & $63.64 \%$ & $27.78 \%$ & $35.55 \%$ \\
\hline South Tangerang & $16.38 \%$ & $18.52 \%$ & $25.00 \%$ & $22.00 \%$ & $20.47 \%$ \\
\hline Bekasi & $28.57 \%$ & $23.33 \%$ & $49.10 \%$ & $19.34 \%$ & $30.08 \%$ \\
\hline Depok & $32.00 \%$ & $51.52 \%$ & $25.00 \%$ & $40.00 \%$ & $37.13 \%$ \\
\hline
\end{tabular}

Based on average calculation during 2013-2014 released by Indonesia Property (November, 2015), market prices growth in prime locations in Jakarta has reached $18.72 \%$. Meanwhile, based on the analysis carried out by Bank Indonesia from 2010 to 2014, there was an increase in land prices on average of 24.54\% in Jakarta and its surrounding areas. Based on Warta Ekonomi (1990), those figures were lower than the average growth in 1985-1988 which reached 36\%, as quoted by Ferguson and Hoffman (1993). While based on Dowall and Leaf (1991), in the period 1987-1989, the average annual land price growth in 
formal sector of Jakarta was $20.77 \%$. By contrast, in locations with low infrastructure, price growth was still relatively low reaching $29.17 \%$. What about land price growth in other countries? Based on the report from Knight Frank (2014) regarding the increase of premium residential land prices in Asian countries from June 2013 to June 2014, Jakarta was at second rank (23.60\%) after Phnom Penh (25\%) and above Bangkok (20.30\%) (Table 2).

Table 2. Premium residential land price increase in Asia (Knight Frank, 2014)

\begin{tabular}{|c|c|c|c|c|}
\hline Kota & H1 2014 & Q1 2014 & Q2 2014 & Juni 13 - Juni 14 \\
\hline Bangkok & $18.20 \%$ & $9.10 \%$ & $8.30 \%$ & $20.30 \%$ \\
\hline Phnom Penh & $13.70 \%$ & $6.10 \%$ & $7.20 \%$ & $25.00 \%$ \\
\hline Jakarta & $11.60 \%$ & $5.80 \%$ & $5.50 \%$ & $23.60 \%$ \\
\hline Bengaluru & $6.80 \%$ & $6.80 \%$ & $0.00 \%$ & $9.70 \%$ \\
\hline Mumbai & $6.30 \%$ & $2.80 \%$ & $3.40 \%$ & $9.10 \%$ \\
\hline Shanghai & $6.20 \%$ & $6.80 \%$ & $-0.60 \%$ & $18.80 \%$ \\
\hline Tokyo & $1.30 \%$ & $1.30 \%$ & $0.10 \%$ & $7.70 \%$ \\
\hline Guangzhou & $0.40 \%$ & $1.60 \%$ & $-1.20 \%$ & $4.80 \%$ \\
\hline Kuala Lumpur & $0.00 \%$ & $0.00 \%$ & $0.00 \%$ & $9.00 \%$ \\
\hline Singapore & $0.00 \%$ & $0.00 \%$ & $0.00 \%$ & $0.90 \%$ \\
\hline Beijing & $-2.50 \%$ & $-1.80 \%$ & $-0.70 \%$ & $-0.10 \%$ \\
\hline NCR & $-4.90 \%$ & $-4.30 \%$ & $-0.60 \%$ & $-1.50 \%$ \\
\hline Hong Kong & $-4.90 \%$ & $-3.00 \%$ & $-2.00 \%$ & $-8.00 \%$ \\
\hline
\end{tabular}

Compared to other countries in Asia, both on the premium residential or premium office (at least in the period 2013-2014) land price in Jakarta was generally included in the group of cities experiencing land price rapid growth. These data was hard evidence showing that the price of land in Jakarta in particular, and Jabodetabek in general, was already extremely high and even still going higher. Based on the above description, review of current land price was conducted in Jabodetabek by measuring market price, which is the net price of land trading transaction (Table 3).

Table 3. Highest and lowest land price in Jadetabek (primary survey data, 2015)

\begin{tabular}{|c|c|c|c|c|}
\hline City & $\begin{array}{l}\text { Highest Price } \\
\text { (rupiah/square meter) }\end{array}$ & $\begin{array}{c}\text { Highest Price Location (Administrative } \\
\text { Village) }\end{array}$ & $\begin{array}{c}\text { Lowest Price } \\
\text { (rupiah/square meter) }\end{array}$ & $\begin{array}{l}\text { Lowest Price Location } \\
\text { (Administrative Village) }\end{array}$ \\
\hline North Jakarta & $45,000,000$ & West Pademangan & 480,000 & Kamal Muara \\
\hline West Jakarta & $50,000,000$ & Duri Kepa & $1,000,000$ & East Cengkareng \\
\hline Central Jakarta & $72,000,000$ & Gelora & $1,500,000$ & Tanah Tinggi \\
\hline East Jakarta & $12,195,000$ & $\begin{array}{l}\text { Pulo Gadung (Pulo Gadung) and } \\
\text { Cipinang Cimpedak (Kec. Jatinegara) }\end{array}$ & 900,000 & Pinang Ranti \\
\hline South Jakarta & $100,000,000$ & Kuningan Timur & $1,416,000$ & Ciganjur \\
\hline Tangerang & $50,000,000$ & Tanah Tinggi & 285,000 & Karang Anyar \\
\hline Depok & $15,000,000$ & Cinere & 285,000 & Tirta Jaya \\
\hline $\begin{array}{l}\text { South } \\
\text { Tangerang }\end{array}$ & $30,000,000$ & Ciater & 416,000 & West Pamulang Barat \\
\hline Bekasi & $15,000,000$ & Bekasi Jaya & 200,000 & Sumur Batu and Cimuning \\
\hline
\end{tabular}

$\mathbf{x x}=$ Highest Price $\mathbf{x x}=$ Lowest Price

The analysis generated conclusion that the highest price calculated at IDR. 100,000,000/sqm was located at East Kuningan, Setiabudi, and South Jakarta. The lowest price calculated at IDR. 200,000/sqm was located at Sumur Batu and Cimuning, Bantar Gebang, Bekasi. This result suggested that urban development concentration heads to South Jakarta. Meanwhile in Bekasi, land prices were relatively lower. It might be due to existence of industrial areas causing pollutions.

Further investigation showed several reasons that might affect the land price in every administrative village, i.e.; (a) Pademangan has the highest land price in North Jakarta allegedly due to tourism destination named Taman Jaya Ancol and nearby shopping centers. By contrast, Penjaringan has the lowest land price due to its frequent flooding. (b) Kebon Jeruk in West Jakarta has highest land price due to its nearness to port of Merak and has already planned as residential area. Meanwhile, Cengkareng has low land price due to its proximity to Soekarno-Hatta Airport that produce high noise pollution. (c) Tanah Abang in Central Jakarta has the highest land price because it is located near to SCBD and center of urban economic activity. While, Johar Baru has lower price due to the presence of slums and Betawi villages having negative image. 
(d) The highest land price at East Jakarta is located in Pulo Gadung due to its civic center with full facilities and Jatinegara due to further development as luxury housing. While, the lowest land price is found at Makassar since the density of this area is already too high and further development is difficult to be conducted. (e) In South Jakarta, the highest price is at Setiabudi due to the proximity to SCBD civic center as well as its function allocation for ambassador housings, while the lowest land price is located at Jagakarsa due to its poor accessibility and location on the outskirts of Jakarta. (f) Tangerang has the highest land price due to its function as government area as well as its development for luxury housings. By contrast, the lowest land price area was located in Batu, Ceper, due to its proximity to international airport and factories. In addition, frequent flooding could aggravate the condition. (g) Cinere holds the highest land price in Depok City because it has closest access to Jakarta, and it has many urban amenities. Meanwhile, the lowest land price is in Sukmajaya due to its proximity to industrial area that produces pollution. (h)The district with the highest price in South Tangerang is Serpong due to its accessibility to the motorway and luxury housings (BSD and Gading Serpong). As opposed, the lowest price is located in Pamulang due to its limited access. (i) East Bekasi has the highest land prices in Bekasi as it is being developed as residential center, while Bantar Gebang has the lowest price due to its nearness to Bantar Gebang Landfill.

Based on market prices, information about land prices was then reanalyzed to determine its growth trend. The market price included not only land but also property prices. According to Ali Tranghada (Executive Director of Indonesia Property Watch / IPW), during the European crisis in 2007-2008, property market in Indonesia began to accelerate in 2009. It can be observed using two indicators: interest rates and purchasing power (DBS Group Research, 2014a). It is estimated that within 3-4 years after the acceleration, booming will usually occur. In fact, Indonesian property market grows of about $50-60 \%$ in one year. The highest growth occurred in three locations: Serpong, Pantai Indah Kapuk and Kelapa Gading.

Property market in Indonesia is unique because developer determines the price. This results in property prices that continue to rise until it becomes overvalued in which it will create speculation. However, this increasing price will arrive at a saturation point. In 2014-2015, the property was at its lowest stage. In sense, the prices are still rising but at a slower pace and are waiting for the moment to go back up. It is estimated that the price increase will be re-started in 2016. The property price and land prices rise in Jabodetabek in the last 5 years (2010-2014) ranging from 5 to 50\% each year. The increase varies in each city.

In this study, land price data for the last 5 years (2010-2014) was utilized. Information about property prices and land prices were obtained by directly asking to an administrative staff and two brokers in every administrative village. However, for some reason, the collected information was incomplete. Therefore, data interpolation was conducted so that all data in the last 5 years were encountered. Furthermore, the interpolated land price data was then summarized into one number for every year, taken from the median price of all the data in each city. It should be emphasized, that the Figure 3 and Figure 4 only describes the growth of price uniquely, but not portrays the real price per year.

Figure 3. Growth of Property Price in Jabodetabek, 2010-2014

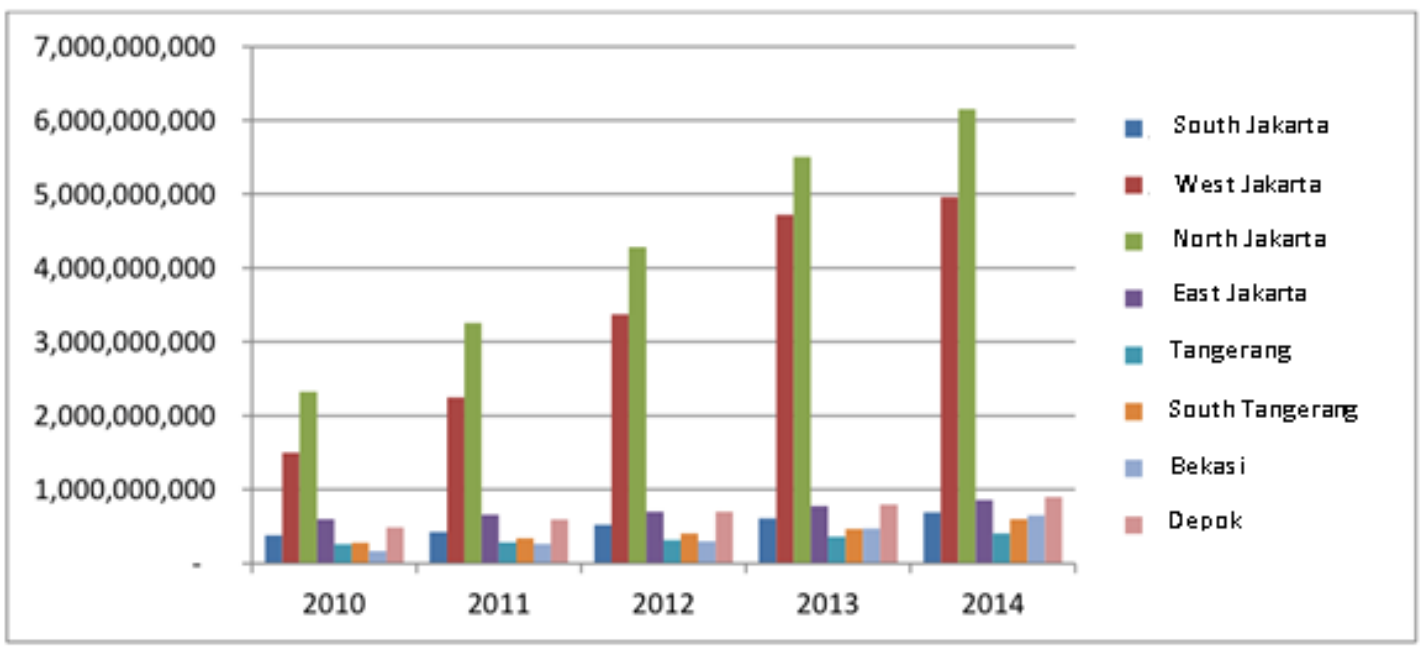


Figure 4. Growth of Land Price in Jabodetabek, 2010-2014

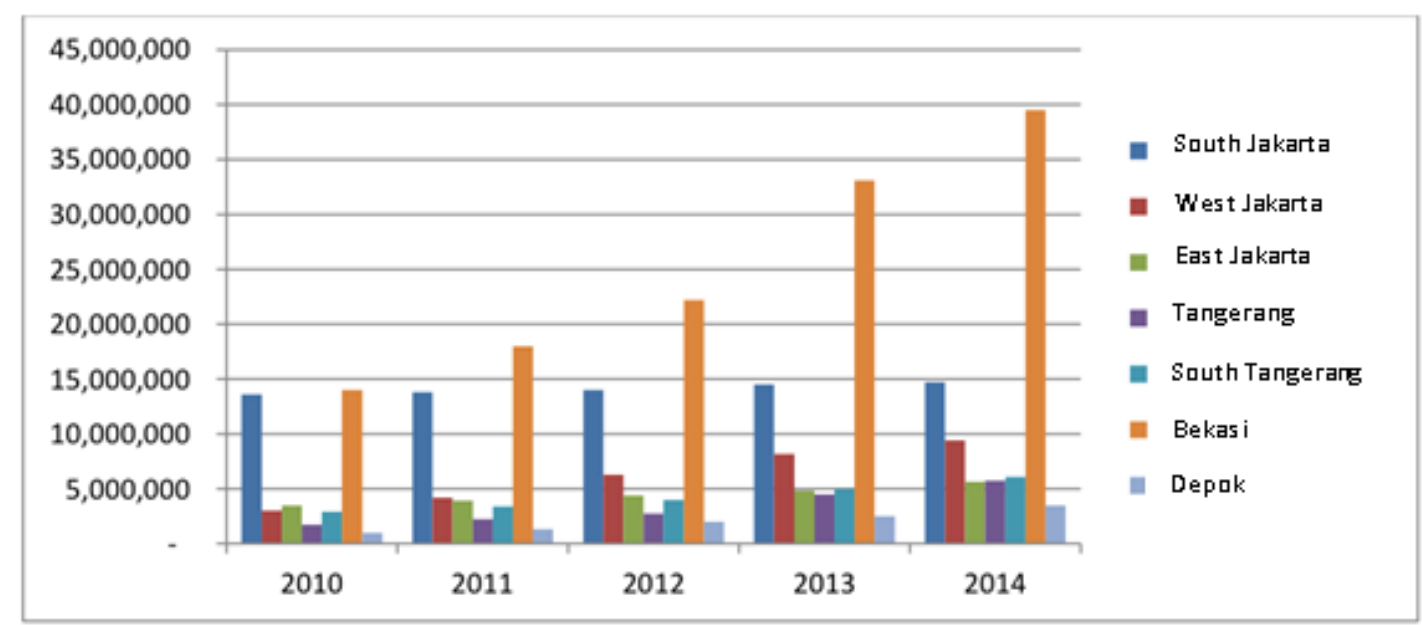

Based on this analysis, North Jakarta has the highest property price in the last 5 years, while the information of land price growth is not available. Tangerang and Bekasi have the lowest property prices throughout the five years in a row. However, in this period, the land price in Bekasi is continuously the highest, far than other areas in Jabodetabek. These land prices is so high, it become barrier for housing supply, so that the property in Bekasi has the lowest price.

Another outcome land price data is isolines map. This map was formed out using land price data that has been normalized using natural logarithm method, and combined with contour lines of land price drawn using interpolation method. This interpolation method was used to determine the similarity of values between the adjacent survey points, then, land price data that has same range of values were grouped. Isolines map shown below has not currently counted the diversity of the existing value. Isolines used to show the distribution of land price values and showed which areas having similar characteristics (Figure 5).

Isolines map showed that there is a vast difference between the price of land in Jakarta, Tangerang, South Tangerang, Bekasi and Depok. Figure 5 showed the distribution of the highest land prices spreading in South Jakarta, Central Jakarta, North Jakarta and West Jakarta. Furthermore, dominance altitude land prices were concentrated in South Jakarta. On the other hand, land price in North Jakarta also begins to increase especially in the border area such as East Jakarta, South Tangerang, and Depok. In addition, land price in Tangerang has not shown a significant growth compared to other regions in Jadetabek.

Figure 5. Land price isoline map (Analysis, 2016)

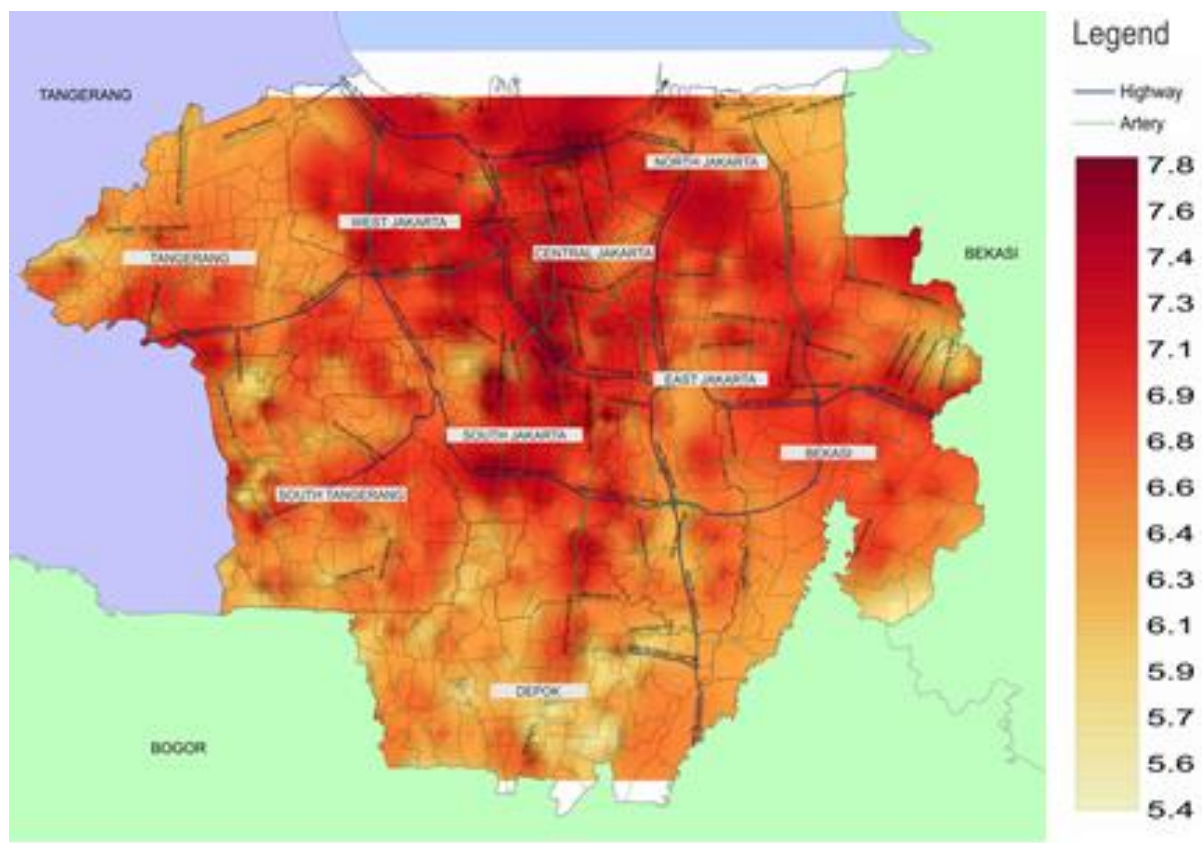




\subsection{Land Bank Ownership in Jabodetabek}

As described earlier, the high growth of land prices has allegedly caused the practice of land ownership by the developer in the form of land bank. Land ownership has at least explained two things: (1) the ability of developer to master a greater market share both today and in the future (2) the indicator of the developer's financial strength, and (3) the ability to influence the price to be offered to the market.

Land ownership through land banking practice or land reserves for future development intends to accumulate land for some time before the development process begins. It is logical, because the land market is not perfect, and the process of land transactions often cannot be quickly resolved. In some cases, the land reserves of developers are used as insurance to obtain assistance from financial institutions, to fund ongoing project developments. Besides, the land reserves can be media speculations for expecting greater price increases in the future. Based on these considerations, the developer will increase the number of their land reserves, because it is extremely important for their businesses sustainability. Based on the analysis of annual and quarterly reports as well as the company's data, an illustration of the land reserves in Jabodetabek which are owned by large developers can be obtained as follow (Table 4).

Table 4. Land bank ownership by large developers in Jabodetabek

\begin{tabular}{|c|c|c|}
\hline No & Developers & Land Bank Area in Jabodetabek (ha) \\
\hline 1 & PT Bumi Serpong Serpong Damai Tbk & $2,931.76$ \\
\hline 2 & PT Alam Sutera Realty Tbk & $2,135.00$ \\
\hline 3 & PT Jaya Real Property Tbk & $1,706.11$ \\
\hline 4 & PT Suryamas Dutamakmur Tbk & $1,599.12$ \\
\hline 5 & PT Kawasan Industri Jababeka Tbk & $1,249.11$ \\
\hline 6 & PT. Modernland Realty Tbk & $1,237.78$ \\
\hline 7 & PT Hanson International Tbk & $1,234.00$ \\
\hline 8 & PT Sentul City Tbk & $1,193.77$ \\
\hline 9 & PT MNC Land Tbk & $1,037.19$ \\
\hline 10 & PT Summarecon Agung Tbk & 943.84 \\
\hline 11 & PT Lippo Cikarang Tbk & 930.00 \\
\hline 12 & PT Duta Pertiwi Tbk & 894.70 \\
\hline 13 & PT. Bakrie Land Tbk & 720.05 \\
\hline 14 & PT Ciputra Development Tbk & 603.80 \\
\hline 15 & PT Intiland Development & 470.31 \\
\hline 16 & PT. Metropolitan Land Tbk & 416.40 \\
\hline 17 & PT. Lippo Karawaci Tbk & 165.00 \\
\hline 18 & PT Megapolitan Development Tbk & 81.85 \\
\hline 19 & PT Metropolitan Kentjana Tbk & 59.85 \\
\hline 20 & PT Pembangunan Jaya Ancol Tbk & 20.39 \\
\hline 21 & PT. Gading Development & 20.00 \\
\hline 22 & PT Bekasi Asri Pemula Tbk & 19.24 \\
\hline 23 & PT Pakuwon Jati Tbk & 15.60 \\
\hline 24 & PT Agung Podomoro Land Tbk & 11.85 \\
\hline 25 & PT Duta Anggada Realty Tbk & 7.01 \\
\hline 26 & PT Perdana Gapuraprima tbk & 3.93 \\
\hline & Total Area of Land Bank (ha) & $19,707.66$ \\
\hline
\end{tabular}


According to data collection, reserve land owned by a private developer who has become a public company is $19,707.66$ hectares of surface. Assuming that one hectare could be built into 50 houses, then, these land banks owned by developers can accommodate as many as 985,400 housing units. Assuming one housing unit is habituated by 4 people (Winarso, 1999), land bank as describe above, could accommodate 4.24 million inhabitants.

It is estimated that the needs/demands for a new house in Jabodetabek, are 170 thousand units per year, but the absorption is still expected to remain below $70 \%$ of that amount (DBS Group Research, 2014b). Thus, assuming absorption is amounted to 119 thousand houses per year, land banking could meet the housing needs in Jabodetabek for the next 8 years.

Figure 6. Land ownership in Jabodetabek (Analysis, 2015)

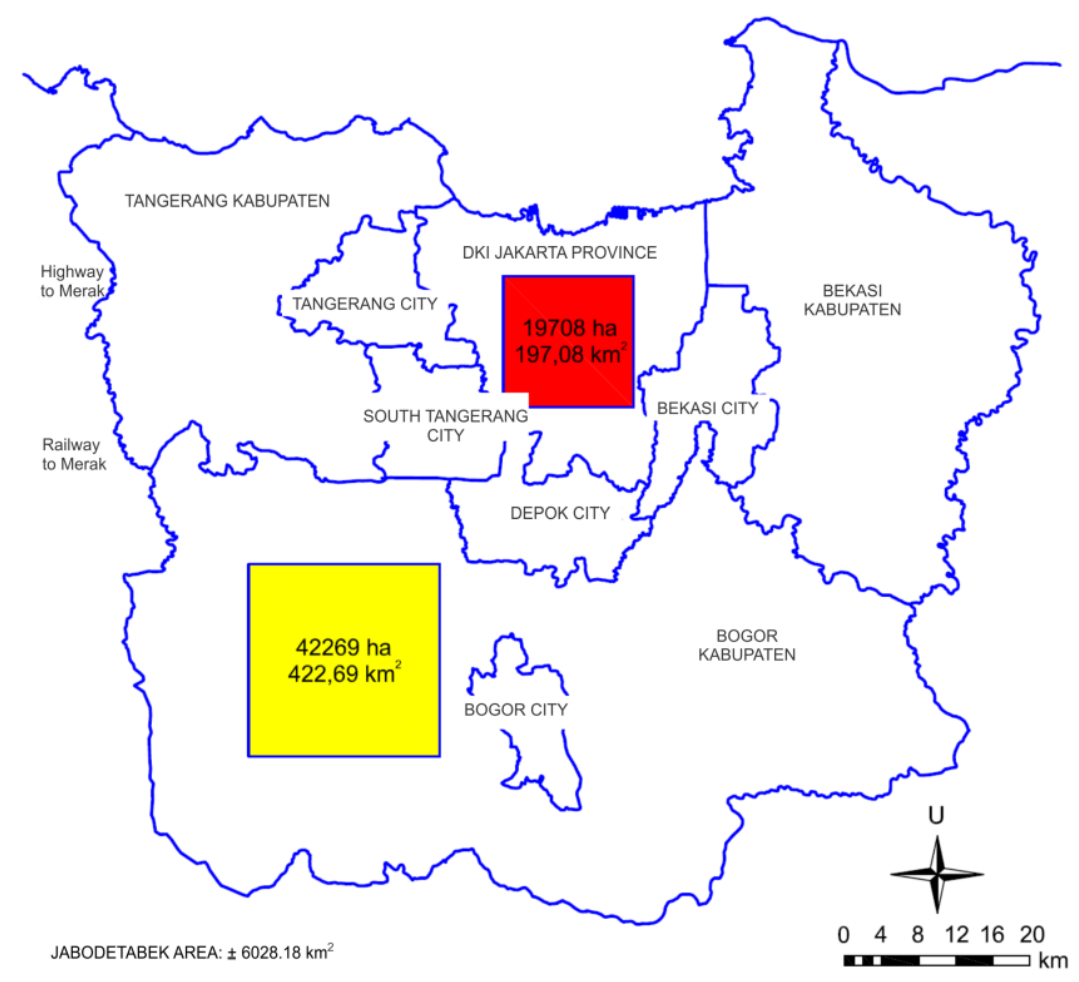

Compared with the total Jabodetabek area reaching 602,818 ha, the land bank owned by the big developers only touch $3 \%$ of it. But when compared with Jakarta which covers 66,233 ha, the percentage rises to $29.76 \%$. The following illustration provides an overview of the extent of land banks owned by large developers, in comparison to the residential projects in Jabodetabek. Overall, residential projects in Jakarta surfacing 42,269 hectares are compared to only $7 \%$ of the Jabodetabek area, but reaches $60 \%$ of the area of Jakarta (Figure 6).

In the previous discussed general problems of land prices in Jabodetabek, the increase was fairly high. Similarly, when compared to other cities in Asia, Jakarta belongs to cities with high price rises. From the outcome analysis, there are several important findings in this study: (a) the increased of land price in Jakarta and its surrounding area is relatively faster than many variables. Similar cases were found when compared to some other cities in Asia. (b) In general, the residential market in Jabodetabek, as many as 19 projects or $4.79 \%$ of the total 397 numbers of residential projects, contributing to $75.65 \%$ or 31,976 hectares of the total area of residential projects Jabodetabek, amount to 42,270 hectares. From these 19 projects, there are developers who control more than one large-scale residential project. (c) Ownership of land bank by developers in Jabodetabek is quite high. At least 19,707 hectares of land reserves are controlled by a small number of developers. (d) Developers regularly raise the land price in the developed project, as an attempt to attract the purchase of the property, equally as an investment instrument by offering property price that increases faster than other investment instruments. 


\section{CONCLUSION}

The growth of land price in Jabodetabek has been proved to be extremely high when compared to other cities in Indonesia and some major cities in Asia. The highest land prices were found at East Kuningan, Setiabudi, and South Jakarta. By constrast, the lowest prices were observed in Sumur Batu and Cimuning (Bantar Gebang, Bekasi). It showed that urban activity is moving to south Jakarta. Land price increase also triggered land banking practice in Jabodetabek reaching in total approximately $60 \%$ of total area of Jakarta.

\section{ACKNOWLEDGMENTS}

This research was funded partially by Penelitian Unggulan Perguruan Tinggi DIKTI (PUPT DIKTI, 2016) and partially by Bank Indonesia (BI, 2015).

\section{REFERENCES}

Alexander, H. B. (2014). 'Siap-siap... Harga Rumah Bakal Naik Lagi!', Kompas, 28 October. Available at: http://properti.kompas.com/read/2014/10/28/122852321/Siap-siap.Harga.Rumah.Bakal.Naik.Lagi.

Beckert, J. (2011). Where do prices come from? Sociological approaches to price formation. Socio-Economic Review, 9(4), 757-786. [CrossRef]

Darin-Drabkin, H. (2013). Land Policy and Urban Growth: Pergamon International Library of Science, Technology, Engineering and Social Studies. Elsevier Science. [Google Book]

DBS Group Research. (2014a). Tread carefully. Indonesia Property Sector. Retrieved from DBS Treasures

DBS Group Research. (2014b). When the going gets tough. Indonesia Property Sector. Retrieved from DBS Treasures

Dowall, D. E., \& Leaf, M. (1991). The Price of Land for Housing in Jakarta. Urban Studies, 28(5), 707-722. [CrossRef]

Ferguson, B. W., \& Hoffman, M. L. (1993). Land markets and the effect of regulation on formal-sector development in urban Indonesia. Review of Urban \& Regional Development Studies, 5(1), 51-73.

Healey, P. (1992). An institutional model of the development process. Journal of Property Research, 9(1), 33-44.

Healey, P., \& Barrett, S. M. (1990). Structure and agency in land and property development processes: some ideas for research. Urban Studies, 27(1), 89-103.

Hermawan, A., \& Syahbana, J. (2015). Pemetaan Perkembangan Perhotelan Di Pusat Perdagangan Dan Jasa Kota Semarang Dengan Sistem Informasi Geografis. Geoplanning: Journal of Geomatics and Planning, 2(1), 38-50. [CrossRef]

$\mathrm{Hu}$, S., et al. (2016). Spatially non-stationary relationships between urban residential land price and impact factors in Wuhan city, China. Applied Geography, 68, 48-56. [CrossRef]

Liu, Z., Miao, J., \& Zha, T. (2016). Land prices and unemployment. Journal of Monetary Economics, 80, 86105. [CrossRef]

Liu, Z., Wang, P., \& Zha, T. (2013). Land-Price Dynamics and Macroeconomic Fluctuations. Econometrica, 81(3), 1147-1184. [CrossRef]

Supriyadi, A. (2014). Pengembang Properti Tuntut Subsidi Uang Muka. CNN Indonesia, 20 November. Available at: http://www.cnnindonesia.com/ekonomi/20141120130255-92-12731/pengembangproperti-tuntut-subsidi-uang-muka/

Tsutsumi, M., \& Seya, H. (2008). Measuring the impact of large-scale transportation projects on land price using spatial statistical models. Papers in Regional Science, 87(3), 385-401. [CrossRef]

Ward, P., Jimenez, E., \& Jones, G. (1993). Residential land price changes in Mexican cities and the affordability of land for low-income groups. Urban Studies, 30(9), 1521-1542.

Winarso, H. (1999). Private residential developers and spatial structure of Jabotabek. Urban Growth and Development in Asia, 1, 277-304.

Winarso, H., \& Firman, T. (2002). Residential land development in Jabotabek, Indonesia: triggering economic crisis? Habitat International, 26(4), 487-506.

Zhang, X., et al. (2017). Industrial land price between China's Pearl River Delta and Southeast Asian regions: Competition or Coopetition? Land Use Policy, 61, 575-586. [CrossRef] 